\section{Heterologous Expression of a Carrot Small Heat Shock Protein Increased Escherichia coli Viability under Lead and Arsenic Stresses}

\author{
Joohee Lee and Yeh-Jin Ahn' \\ Department of Life Science, College of Natural Sciences, Sangmyung \\ University, 20 Hongjimun 2-gil, Jongno-gu, Seoul 110-743, Korea
}

Additional index words. abiotic stress tolerance, Daucus carota, heavy metal, metalloid

\begin{abstract}
The expression and function of DcHsp17.7, a small heat shock protein (sHSP), in carrot (Daucus carota $\mathrm{L}$.) was examined under lead $[\mathrm{Pb}(\mathrm{II})]$ and arsenic (arsenate) stresses. In a time course experiment, the level of DcHsp17.7 increased in carrot leaf tissue treated with lead ions or arsenate. To examine the function of DcHsp17.7, the DcHsp17.7 gene was cloned and introduced into Escherichia coli. Heterologous expression of DcHsp17.7 was confirmed by immunoblot analysis using a polyclonal antibody raised against DcHsp17.7. Lead ion and arsenate reduced bacterial cell viability. However, transgenic $E$. coli with accumulated DcHsp17.7 showed higher levels of survival under both lead ion and arsenate conditions compared with the vector control. Immunoblot analysis showed that the level of heterologously expressed DcHsp17.7 decreased under lead ion conditions, but remained the same under arsenate conditions. Our results suggest that DcHsp17.7 can confer tolerances to lead and arsenic stresses.
\end{abstract}

Heat shock proteins are a group of proteins expressed under heat and other abiotic stresses (reviewed in Lindquist and Craig, 1988). They are classified into five different families, HSP100, HSP90, HSP70, HSP60, and sHSP (12 to $42 \mathrm{kDa}$ ), based on their molecular masses. sHSPs are unusually abundant and diverse in plants (19 in Arabidopsis thaliana, Scharf et al., 2001; 23 in Oryza sativa: Waters et al., 2008; 36 in Populous trichocarpa: Waters et al., 2008), compared with other organisms (four in Drosophila melanogaster, 10 in Homo sapiens, 16 in Caenorhabditis elegans; reviewed in Haslbeck et al., 2005), suggesting that sHSPs may confer enhanced protection to abiotic stresses in sessile plants. sHSPs are divided into 11 subfamilies based on their cellular localization and sequence homology (Waters, 2013). There are six subfamilies in the cytoplasm/ nucleus (CI to CVI), two in the mitochondria (MTI and MTII), and one each in the endoplasmic reticulum, peroxisome, and chloroplast. A number of studies have reported that sHSPs function as molecular chaperones by preventing protein denaturation and/or

Received for publication 21 May 2013. Accepted for publication 2 Aug. 2013.

This research was supported by a 2013 Research Grant from Sangmyung University and by the Basic Science Research Program through the National Research Foundation of Korea (NRF) funded by the Ministry of Education (2012-0004406).

We thank Hanseul Park and Eunsun Jang for technical support.

${ }^{1}$ To whom reprint requests should be addressed; e-mail yjahn@smu.ac.kr. restoring folding of partially denatured proteins under abiotic stresses (reviewed in Sun et al., 2002).

Our previous studies have reported that DcHsp17.7, a cytosolic (CI) sHSP in carrot (Daucus carota L.), is expressed under heat (Ahn et al., 2004), cold (Song and Ahn, 2010), salinity (Song and Ahn, 2011) as well as osmotic and oxidation (Ahn and Song, 2012) stresses. Transgenic carrot (Malik et al., 1999) and potato (Solanum tuberosum L.; Ahn and Zimmerman, 2006) plants overexpressing DcHsp17.7 showed increased thermotolerance. When heterologously expressed in E. coli, DcHsp17.7 increased survival rates in a transgenic cell line, compared with vector control, under various abiotic stresses (Ahn and Song, 2012; Kim and Ahn, 2009; Song and Ahn, 2010, 2011), functioning as a molecular chaperone. Our results suggested that DcHsp17.7 could confer tolerances to not only heat, but also multiple abiotic stresses.

In this study, we examined the expression and function of DcHsp17.7 under heavy metal (lead ion) and metalloid (arsenate) stresses. Heavy metal and metalloid contamination poses a serious health risk to all living organisms, including humans and plants. Lead ion enters the food chain through living organisms such as microorganisms, insects, and plants taking up lead from various sources including residues from mining of metalliferous ores, burning of leaded gasoline, and municipal sewage (Gisbert et al., 2003). Within the cell, lead ions can replace essential ions and thus disrupt redox balance (Wang et al., 2011). In plants, lead ion inhibits a number of metabolic processes, including mineral acquisition and phytosynthesis (Brunet et al.,
2009). Arsenate compounds have been widely used in agriculture such as pesticides for insects, fungi, and rodents and wood preservatives (Murcott, 2012). The level of arsenic is rapidly increasing in groundwater and soils (Goswami et al., 2010). Inorganic forms of arsenic, i.e., arsenate and arsenite, are more toxic than the organic forms (Chakrabarty et al., 2009). However, the mechanism(s) of its uptake and translocation is largely unknown in plants.

The production of stress-tolerant proteins is one of the mechanisms that plants and other living organisms have developed to withstand heavy metal contamination. Phytochelatin and methallothionine are the most well-known proteins that bind to and detoxify heavy metals in living organisms (Cobbett and Goldsbrough, 2002). HSPs have also been reported to accumulate under heavy metal conditions, such as lead (HSP70 and HSP60, Solanum lycopersicum, Wang et al., 2008; Spinacia oleraces, Wang et al., 2011) and arsenic (HSP70 in Oryza sativa, Goswami et al., 2010; HSP21 in Crambe abyssinica, Paulose et al., 2010; HSP23 in Nicotiana tabacum, Lee et al., 2012). These results suggest that HSPs may be involved in heavy metal stress tolerance in plants.

\section{Materials and Methods}

Plant materials and heavy metal treatment. Carrot seeds (Daucus carota L. cv. Mussangochon) were sown in a commercial soil mix (Ssaknara; Minong, Seoul, Korea) and grown in a controlled environmental chamber (18 to $21{ }^{\circ} \mathrm{C}, 14-\mathrm{h}$ photoperiod) with light supplied by a fluorescent lamp at an intensity of 200 $\mu \mathrm{E} \cdot \mathrm{m}^{-2} \cdot \mathrm{s}^{-1}$ and a relative humidity of $60 \%$. To examine the expression pattern of DcHsp17.7 under lead and arsenic conditions, leaf tissues detached from 2- to 3-month-old carrot plants were incubated in an $125-\mathrm{mL}$ Erlenmeyer flask containing lead [lead(II) nitrate, $\mathrm{Pb}\left(\mathrm{NO}_{3}\right)_{2}$; Sigma-Aldrich, St. Louis, MO] or arsenic (sodium arsenate dibasic heptahydrate, $\mathrm{Na}_{2} \mathrm{HAsO}_{4} \cdot 7 \mathrm{H}_{2} \mathrm{O}$; Sigma-Aldrich) solutions (at $1 \mathrm{~mm}$ up to $7 \mathrm{~h}$; Lee et al., 2012; Yi et al., 2006). Samples were taken immediately after each time point, frozen in liquid nitrogen, and stored at $-80{ }^{\circ} \mathrm{C}$ until analysis.

Protein extraction from carrot leaf tissue and immunoblot analysis. Protein extraction from carrot tissue, sodium dodecyl sulfatepolyacrylamide gel electrophoresis (SDSPAGE), and immunoblot analysis using a polyclonal antibody raised against $\mathrm{DcHsp} 17.7$ were performed as previously described (Ahn et al., 2004). Briefly, carrot leaf tissue $(0.5 \mathrm{~g})$ was homogenized in extraction buffer I $(1 \mathrm{~mL}$; $0.3 \%$ SDS, $200 \mathrm{~mm}$ dithiothreitol, $28 \mathrm{~mm}$ Tris$\mathrm{HCl}$, and $22 \mathrm{~mm}$ Tris-base). After incubation at $100{ }^{\circ} \mathrm{C}$ for $5 \mathrm{~min}$, the lysate was mixed with extraction buffer II $(100 \mu \mathrm{L} ; 24 \mathrm{~mm}$ Tris-base, $476 \mathrm{~mm}$ Tris- $\mathrm{HCl}, 50 \mathrm{~mm} \mathrm{MgCl}, 1 \mathrm{mg} \cdot \mathrm{mL}^{-1}$ DNase I, and $0.25 \mathrm{mg} \cdot \mathrm{mL}^{-1}$ RNase A) followed by addition of trichloroacetic acid (50\%) to precipitate the proteins. The protein pellet was washed with acetone $(95 \%)$ three times and dissolved in extraction buffer I. The 
concentration of the protein sample was quantified using the Bradford assay (Bradford, 1976). Proteins $(50 \mu \mathrm{g})$ from each sample were resolved on a SDS-PAGE gel (17\%) and electroblotted to a polyvinylidene difluoride membrane (Bio-Rad, Hercules, CA) followed by immunoblot analysis using a polyclonal antibody raised against DcHsp17.7, according to the instructions of the ECL Plus system (GE Healthcare Life Science, Buckinghamshire, U.K.). Chemiluminescent signals were detected on Hyperfilm (GE Healthcare Life Science) and quantified using a densitometer (IMAGER; Bioneer, Seoul, Korea). Experiments were performed three times with two to three leaves per condition.

DcHsp17.7 gene cloning in expression vector. The insert gene was generated by the polymerase chain reaction (one cycle at $94{ }^{\circ} \mathrm{C}$ for $5 \mathrm{~min}$ followed by 35 cycles of $94{ }^{\circ} \mathrm{C}$ for $40 \mathrm{~s}, 68^{\circ} \mathrm{C}$ for $50 \mathrm{~s}$, and $72^{\circ} \mathrm{C}$ for $50 \mathrm{~s}$ ) using a pair of DcHsp17.7 gene-specific (National Center for Biotechnology Information accession number X53851) primers (forward: 5' -GG GGGGCATATGTCGATCATTCCAAGC-3', reverse: 5'-GGGGGGGCTAGCTTAACCAG AAATATCAATGGC-3') and introduced into the Novagen $\mathrm{pET} 11 \mathrm{a}$ expression vector (Merck $\mathrm{KGaA}$, Darmstadt, Germany) at the NdeI and NheI restriction enzyme sites (underlined). The recombinant $\mathrm{pET} 11 \mathrm{a}-\mathrm{DcHsp} 17.7$ expression vector was introduced into $E$. coli $(\mathrm{DH}$ $5 \alpha$; Enzynomics, Daejeon, Korea) through heat shock for $1 \mathrm{~min}$ at $42{ }^{\circ} \mathrm{C}(\mathrm{Kim}$ and $\mathrm{Ahn}$, 2009). After overnight incubation on the selection medium [solid Luria-Bertani medium (LB; BD Difco, Franklin Lakes, NJ) containing 100 $\mu \mathrm{g} \cdot \mathrm{mL}^{-1}$ ampicillin], a positive colony was selected, and the sequence of the recombinant plasmid was confirmed. The recombinant pET11a-DcHsp17.7 plasmid was then transformed into the BL21 (DE3) cell line (Enzynomics) for gene expression.
Heterologous gene expression in E. coli and immunoblot analysis. Transgenic E. coli containing the recombinant pET11a-DcHsp17.7 plasmid and vector control containing the unmodified $\mathrm{pET} 11 \mathrm{a}$ expression vector were cultured in LB (BD Difco) containing 100 $\mu \mathrm{g} \cdot \mathrm{mL}^{-1}$ ampicillin overnight at $37^{\circ} \mathrm{C}$. Bacterial cell cultures were then diluted 1:1000 and continuously cultured. When the growth of bacterial cell cultures reached 0.6 at an $\mathrm{OD}_{600}$, isopropylthio- $\beta$-galactoside (IPTG) was then added to a final concentration of $1 \mathrm{~mm}$ to express the heterologous DcHsp 17.7 gene. After $2 \mathrm{~h}$, bacterial cultures $(50 \mathrm{~mL})$ were centrifuged $\left(2830 \mathrm{~g}\right.$ at $4{ }^{\circ} \mathrm{C}$ for $\left.20 \mathrm{~min}\right)$, and the resulting bacterial pellet was resuspended in extraction buffer $(4 \mathrm{~mL} ; 25 \mathrm{~mm}$ Tris- $\mathrm{HCl} \mathrm{pH} \mathrm{7.5,} 300 \mathrm{~mm} \mathrm{NaCl}$, and $3 \mathrm{~mm}$ $\beta$-mercaptoethanol). Bacterial proteins were extracted by disrupting cells using ultrasonication $(420 \mathrm{~W}, 20 \mathrm{Khz}$ for a total of 4 min and $40 \mathrm{~s}$; repeat of sonication for $10 \mathrm{~s}$ and pause for $30 \mathrm{~s}$ ) using Sonomasher ( $\mathrm{S} \& \mathrm{~T}$ Science, Seoul, Korea). The lysate was centrifuged $\left(20,900 \mathrm{~g}\right.$ at $4{ }^{\circ} \mathrm{C}$ for $\left.1 \mathrm{~h}\right)$, and the supernatant was removed. The bacterial protein concentration was measured using the Bradford assay (Bradford, 1976). To confirm heterologous accumulation of DcHsp17.7 in transgenic E. coli, bacterial proteins $(30 \mu \mathrm{g}$ per lane) were subjected to SDS-PAGE (17\%) and immunoblot analysis as described previously.

Cell viability of $\mathrm{E}$. coli under lead and arsenic stresses. Overnight $E$. coli cell culture, cell dilution, and additional cell culture were performed as described previously. After $2 \mathrm{~h}$ of IPGT treatment, transgenic cell lines accumulating DcHsp17.7 and vector control cell lines containing the unmodified pET11a vector were exposed to lead ion (up to $7 \mathrm{~mm}$ for $1 \mathrm{~h}$ ) or arsenate (up to $50 \mathrm{~mm}$ for $2 \mathrm{~h}$ ) followed by serial dilution of $1: 10^{6}$.
Bacterial cells were then spread on solid LB plates containing $100 \mu \mathrm{g} \cdot \mathrm{mL}^{-1}$ ampicillin. After overnight incubation at $37{ }^{\circ} \mathrm{C}$, the number of surviving colonies was counted, and the percentage of cell viability was calculated. The experiment was independently repeated at least three times (five plates per condition). A paired $t$ test was performed to compare the difference in the level of cell viability between transgenic $E$. coli accumulating DcHsp17.7 and the vector control cell line containing the unmodified pET11a expression vector $(* * P<0.01)$.

Immunoblot analysis of heterologously expressed DcHsp17.7 under lead and arsenic stresses. Overnight cell culture, IPTG treatment, bacterial protein extraction, and protein quantification were performed as described previously. Heavy metals (lead ion up to $20 \mathrm{~mm}$ or arsenate up to $500 \mathrm{~mm}$ ) were added to $2 \mathrm{mg}$ bacterial proteins in $600 \mu \mathrm{L}$ extraction buffer (25 mm Tris- $\mathrm{HCl} \mathrm{pH} 7.5,300 \mathrm{~mm} \mathrm{NaCl}$, and $3 \mathrm{~mm} \beta$-mercaptoethanol) and incubated at $25^{\circ} \mathrm{C}$ for $1 \mathrm{~h}$ or $2 \mathrm{~h}$ for lead ion and arsenate, respectively. Protein samples were then centrifuged $\left(20,900 \mathrm{~g}\right.$ at $4{ }^{\circ} \mathrm{C}$ for $\left.1 \mathrm{~h}\right)$ to precipitate denatured proteins. The supernatant $(22 \mu \mathrm{L}$ per sample) was subjected to SDS-PAGE $(17 \%)$ and immunoblot analysis using a polyclonal antibody raised against DcHsp17.7, as described previously. The relative levels of DcHsp17.7 signals were quantified using a densitometer (IMAGER). Experiments were performed three times with two samples per condition and the most representative images are shown.

\section{Results and Discussion}

DcHsp17.7 accumulated in carrot leaves under lead and arsenic conditions. A timecourse immunoblot analysis was performed to examine the accumulation pattern of

\section{A. Lead ion}
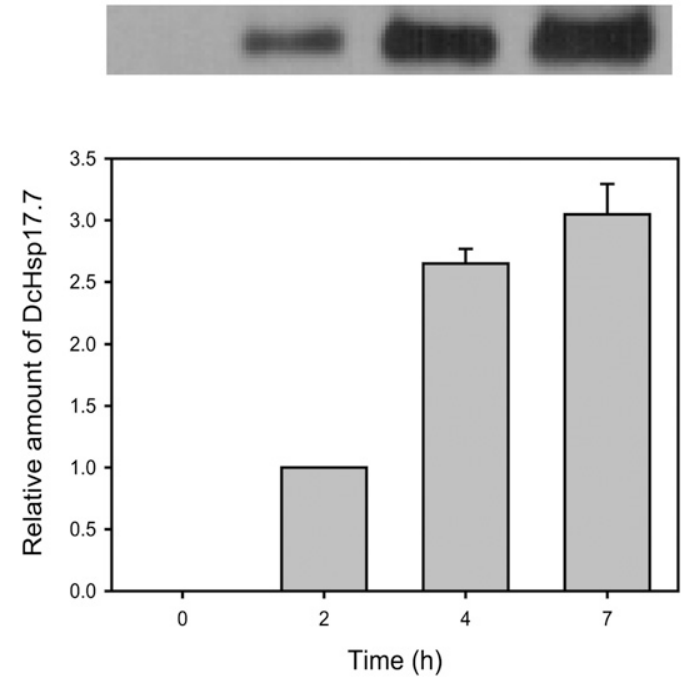

\section{B. Arsenate}
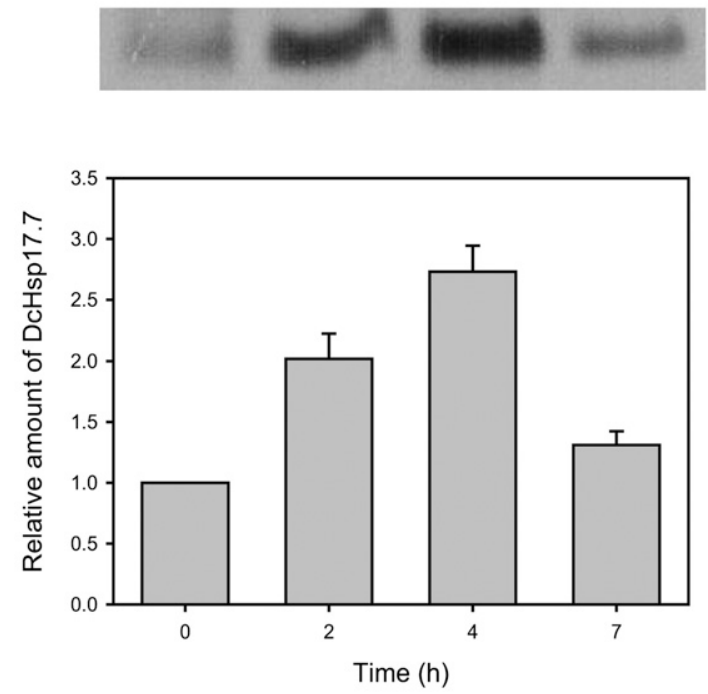

Fig. 1. Accumulation pattern of DcHsp17.7 in carrot leaf tissues under lead and arsenic conditions. Carrot (Daucus carota L.) leaf tissues were exposed to lead ion or arsenate ( $1 \mathrm{~mm}$ in distilled water) for up to $7 \mathrm{~h}$. Proteins were extracted under denaturing conditions, and an equal amount (50 $\mu \mathrm{g}$ protein per sample) was subjected to sodium dodecyl sulfate-polyacrylamide gel electrophoresis (SDS-PAGE) and immunoblot analysis using a polyclonal antibody raised against DcHsp17.7. The size of the signal was $\approx 18 \mathrm{kDa}$. 
DcHsp17.7 under lead and arsenic conditions. In non-stressed leaf tissue, DcHsp17.7 was not present or present at a low level (Fig. 1 ), as shown in our previous study (Ahn et al., 2004). On exposure to lead ion and arsenate, the level of DcHsp17.7 gradually increased ( $\approx 3$-fold). In arsenate-treated leaf tissue, the level of DcHsp17.7 decreased at a later time point $(7 \mathrm{~h})$. The expression of DcHsp17.7 suggests that the protein could be involved in lead and arsenic stress tolerance in plant cells.

Heterologously expressed DcHsp17.7 enhanced bacterial cell viability under lead and arsenic conditions. To examine if DcHsp17.7 can confer tolerance to lead and arsenic stresses, the DcHsp 17.7 gene was introduced into $E$. coli, which is

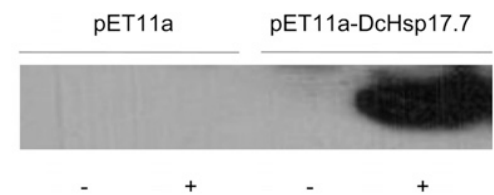

Fig. 2. Heterologous accumulation of DcHsp17.7 in transgenic $E$. coli. The coding sequence of the DcHsp17.7 gene was inserted into the pET11a expression vector. The recombinant plasmid was then introduced into $E$. coli and heterologous expression of DcHsp17.7 was induced by isopropylthio- $\beta$-galactoside (IPTG) treatment. Bacterial proteins from the transgenic E. coli containing the recombinant pET11a-DcHsp17.7 expression vector and from the vector control cell line containing the unmodified pET11a vector were extracted using ultra-sonication. An equal amount $(30 \mu \mathrm{g}$ per lane) of protein was subjected to sodium dodecyl sulfate-polyacrylamide gel electrophoresis (SDS-PAGE) and immunoblot analysis using a polyclonal antibody raised against DcHsp17.7. The size of the signal was $\approx 18 \mathrm{kDa}$. a convenient model to study protein function. Studies have shown that some HSPs, whose heterologous expression increased cell viability in $E$. coli under abiotic stress conditions, also conferred tolerances to the stresses in overexpression transgenic plants. For example, Jiang et al. (2009) reported that a cytosolic CI sHSP, RcHSP17.8, in Rosa chinensis conferred tolerances to various abiotic stresses in E. coli, yeast, and Arabidopsis. More recently, Lee et al. (2012) reported that transgenic tobacco plants (Nicotiana tabacum) overexpressing alfalfa mitochondrial Hsp23 and transgenic $E$. coli heterologously expressing the protein showed increased tolerance to salinity and arsenate stresses. On IPTG treatment, DcHsp17.7 protein accumulated in the transgenic E. coli containing the pET11aDcHsp17.7 recombinant vector (Fig. 2). Without IPTG treatment, the transgenic cell line did not produce the protein, suggesting that the heterologous expression of DcHsp17.7 was tightly controlled in E. coli. A control cell line containing the unmodified pET11a vector did not produce a signal regardless of IPTG treatment.

In our previous study, heterologously expressed DcHsp17.7 increased bacterial cell viability under a number of abiotic stresses (Ahn and Song, 2012; Kim and Ahn, 2009; Song and Ahn, 2010, 2011), suggesting that DcHsp17.7 may confer tolerance to multiple abiotic stresses. In this study, we examined the changes in the bacterial cell viability in the presence of hetelorogously expressed DcHsp17.7 under lead and arsenic stresses. Under the stresses, bacterial cell viability decreased in a concentration-dependent manner (Fig. 3). On a molar basis, lead ion reduced bacterial cell survival rates more than arsenate. However, the transgenic E. coli expressing DcHsp17.7 showed a higher level of cell viability (by $\approx 10 \%$ to $30 \%$ ) under the both stress conditions compared with the vector control cells.

HSPs are molecular chaperones, which perform a number of activities such as protein folding/unfolding, assembly/disassembly, translocation, and degradation (Waters, 2013). Under stress conditions, HSPs detect unusual hydrophobic surfaces of denatured proteins and bind them either to correct the folding or to prevent from further degradation. Heavy metals reduce cellular proteins breaking disulfide bonds and some metals are reported to interact with hydroxyl and carboxyl groups (Sahr et al., 2005), destabilizing the normal structure and function of proteins. It is possible that DcHsp17.7 interacts with a broad range of bacterial proteins disrupted by lead ion or arsenate and performs molecular chaperone activity, resulting in increased cell viability.

Heterologously expressed DcHsp17.7 was more stable under arsenic than under lead stress. The level of heterologously expressed DcHsp17.7 in transgenic E. coli was examined under lead ion and arsenate stresses. Immunoblot analysis showed that the level of heterologously expressed DcHsp17.7 significantly decreased as the concentration of lead ion increased (Fig. 4A), although it remained unchanged under arsenate conditions (up to $500 \mathrm{~mm}$; Fig. 4B). Considering the fact that the bacterial cell viability decreased to less than $20 \%$ at $50 \mathrm{~mm}$ arsenate (Fig. 3B), it is noteworthy that the heterologously expressed DcHsp17.7 was very stable up to $500 \mathrm{~mm}$ arsenate.

This study showed that heterologously expressed DcHsp17.7 can confer resistance to lead and arsenic stresses in transgenic E. coli. We have previously reported that

\section{A. Lead ion}

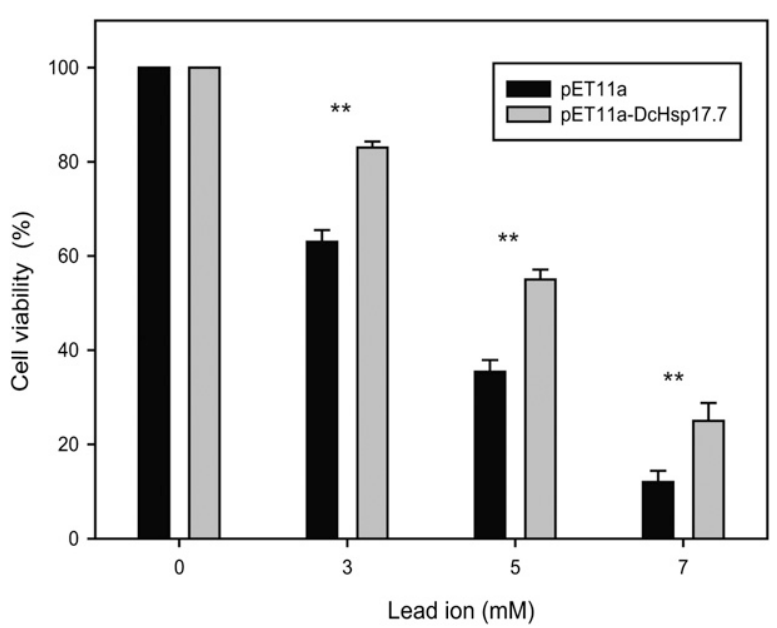

\section{B. Arsenate}

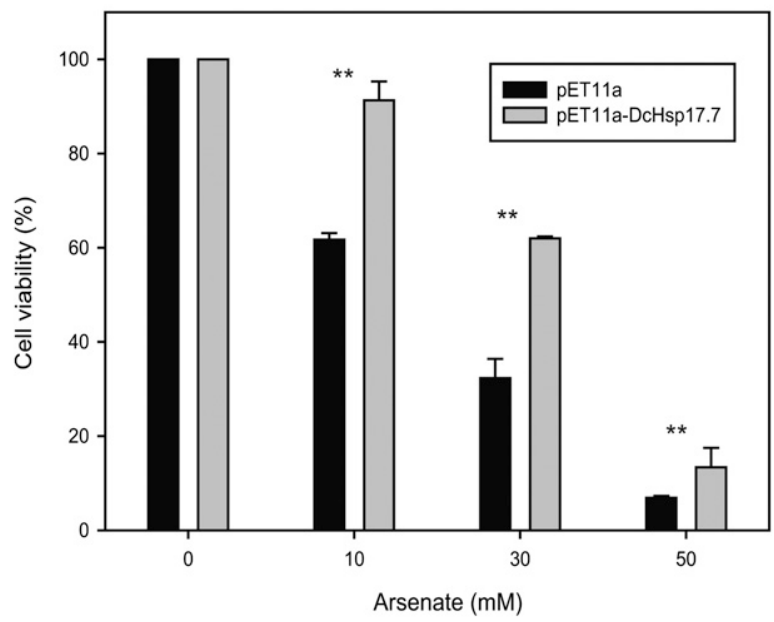

Fig. 3. Bacterial cell viability under lead and arsenic conditions. Bacterial cell culture was performed as described in "Materials and Methods." After $2 \mathrm{~h}$ of isopropylthio- $\beta$-galactoside (IPTG) treatment, bacterial cell cultures were exposed to lead ion (up to $7 \mathrm{~mm}$ for $1 \mathrm{~h}$ ) or arsenate (up to $50 \mathrm{~mm}$ for $2 \mathrm{~h}$ ). After a serial dilution of $1: 10^{6}$, bacterial cells were plated on solid LB medium containing ampicillin and incubated overnight. The number of surviving colonies was then counted, and the percentage of cell viability, compared with non-stressed control, was calculated. The error bars show the SEM. A paired $t$ test was performed to compare the differences in cell viability between the transgenic E. coli accumulating DcHsp17.7 and the vector control cell line containing the unmodified pET11a expression vector $(* * P<0.01)$. 


\section{A. Lead ion}
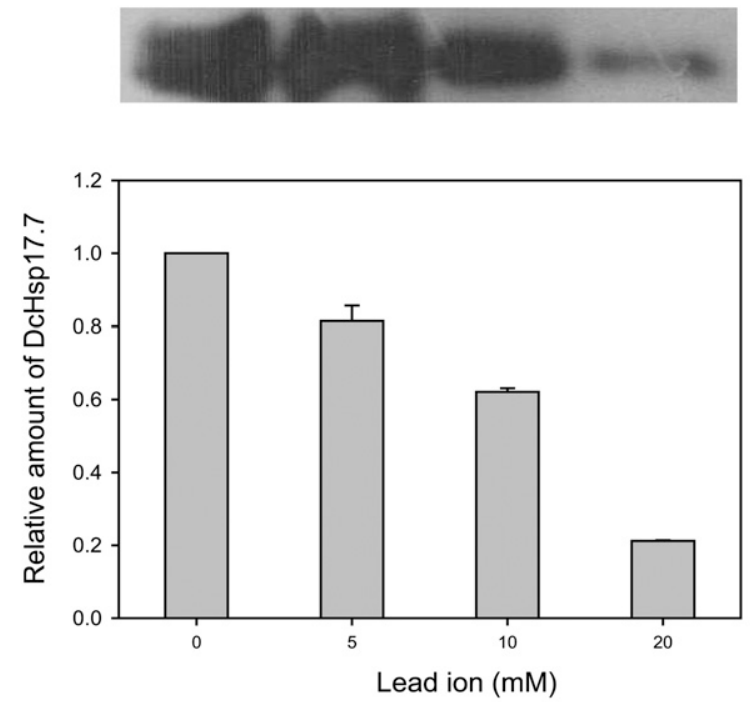

\section{B. Arsenate}
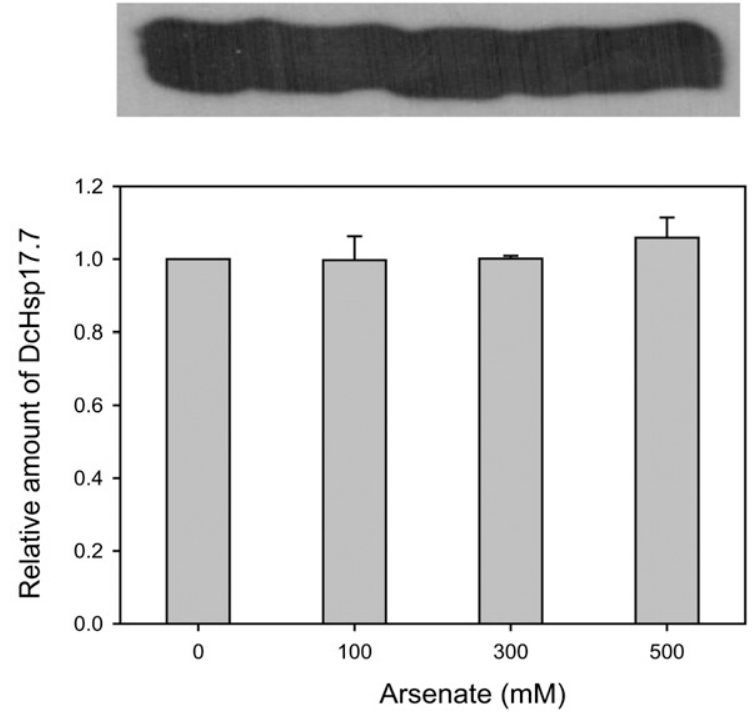

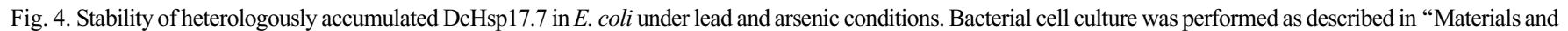
Methods." After $2 \mathrm{~h}$ of isopropylthio- $\beta$-galactoside (IPTG) treatment, bacterial proteins were extracted and exposed to lead ion (up to $20 \mathrm{~mm}$ for $1 \mathrm{~h}$ ) or arsenate (up to $500 \mathrm{~mm} 2 \mathrm{~h}$ ). Protein samples were then centrifuged and the supernatant containing soluble proteins was subjected to sodium dodecyl sulfate-polyacrylamide gel electrophoresis (SDS-PAGE) and immunoblot analysis using a polyclonal antibody raised against DcHsp17.7. The molecular weight of the band was $\approx 18 \mathrm{kDa}$.

overexpression of DcHsp17.7 increased thermotolerance in transgenic carrot and potato plants (Ahn and Zimmerman, 2006; Malik et al., 1999). Heterologously expressed DcHsp17.7 also conferred tolerances to various abiotic stresses in transgenic $E$. coli as described previously. These results suggest that DcHsp17.7 may confer tolerances to multiple abiotic stresses, which are present in the actual field conditions. DcHsp17.7 could be useful for plant genetic engineering for multiple stress tolerance.

\section{Literature Cited}

Ahn, Y.-J., K. Claussen, and J.L. Zimmerman. 2004. Genotypic differences in the heat shock response and thermotolerance in four potato cultivars. Plant Sci. 166:901-911.

Ahn, Y.-J. and N.-H. Song. 2012. A cytosolic heat shock protein expressed in carrot (Daucus carota $\mathrm{L}$.) enhances cell viability under oxidative and osmotic stress conditions. HortScience 47:143-148.

Ahn, Y.-J. and J.L. Zimmerman. 2006. Introduction of the carrot HSP17.7 into potato (Solanum tuberosum L.) enhances cellular membrane stability and tuberization in vitro. Plant Cell Environ. 29:95-104.

Bradford, M.M. 1976. A rapid and sensitive method for the quantitation of microgram quantities of protein utilizing the principle of protein-dye binding. Anal. Biochem. 72:248-254.

Brunet, J., G. Varrault, Y. Zuily-Fodil, and A. Repellin. 2009. Accumulation of lead in the roots of grass pea (Lathyrus sativa L.) plants triggers systematic variation in gene expression in the shoots. Chemosphere 77:1113-1120.

Chakrabarty, D., P.K. Trivedi, P. Misra, M. Tiwari, M. Shri, D. Shukla, S. Kumar, A. Rai, A. Pandey, D. Nigam, R.D. Tripathi, and R. Tuli. 2009. Comparative transcriptome analysis of arsenate and arsenite stresses in rice seedlings. Chemosphere 74:688-702.

Cobbett, C. and P. Goldsbrough. 2002. Phytochelatins and metallothioneins: Roles in heavy metal detoxification and homeostasis. Annu. Rev. Plant Biol. 2002:159-182.

Gisbert, C., R. Ros, A. De Haro, D.J. Walker, M.P. Bernal, R. Serrano, and J. Navarro-Aviñó. 2003. A plant genetically modified that accumulates $\mathrm{Pb}$ is especially promising for phytoremediation. Biochem. Biophys. Res. Commun. 303:440-445.

Goswami, A., R. Banerjee, and S. Raha. 2010. Mechanisms of plant adaptation/memory in rice seedlings under arsenic and heat stress: Expression of heat-shock protein gene HSP70. AoB Plants 2010:plq023.

Haslbeck, M., T. Franzmann, D. Weinfurtner, and J. Buchner. 2005. Some like it hot: The structure and function of small heat-shock proteins. Nat. Struct. Mol. Biol. 12:842-846.

Jiang, C., J. Xu, H. Zhang, J. Shi, M. Li, and F. Ming. 2009. A cytosolic class I small heat shock protein, RcHSP17.8, of Rosa chinensis confers resistance to a variety of stresses to Escherichia coli, yeast and Arabidopsis thaliana. Plant Cell Environ. 32:1046-1069.

Kim, H. and Y.-J. Ahn. 2009. Expression of a gene encoding the carrot HSP17.7 in Escherichia coli enhances cell viability and protein solubility under heat stress. HortScience 44:866-869.

Lee, K.W., J.Y. Cha, K.H. Kim, Y.G. Kim, B.H Lee, and S.H. Lee. 2012. Overexpression of alfalfa mitochondrial HSP23 in prokaryotic and eukaryotic model systems confers enhanced tolerance to salinity and arsenicstress. Biotechnol. Lett. 34:167-174.

Lindquist, S. and E.A. Craig. 1988. The heat-shock proteins. Annu. Rev. Genet. 22:631-677.

Malik, M.K., J.P. Slovin, C.H. Hwang, and J.L. Zimmerman. 1999. Modified expression of a carrot small heat shock protein gene, hsp17. 7 , results in increased or decreased thermotolerance. Plant J. 20:89-99.

Murcott, S. (ed.). 2012. Arsenic contamination in the world: An international sourcebook. IWA Publishing, London, UK. p. 29.

Paulose, B., S. Kandasamy, and O.P. Dhankher. 2010. Expression profiling of Crambeabyssinica under arsenate stress identifies genes and gene networks involved in arsenic metabolism and detoxification. BMC Plant Biol. 10:108.
Sahr, T., G. Voigt, H.G. Paretzke, P. Schramel, and D. Ernst. 2005. Caesium-affected gene expression in Arabidopsis thaliana. New Phytol. 165: 747-754.

Scharf, K.D., M. Siddique, and E. Vierling. 2001. The expanding family of Arabidopsis thaliana small heat stress proteins and a new family of proteins containing alpha-crystallin domains (Acd proteins). Cell Stress Chaperones 6:225237.

Song, N.-H. and Y.-J. Ahn. 2010. DcHsp17.7, a small heat shock protein from carrot, is upregulated under cold stress and enhances cold tolerance by functioning as a molecular chaperone. HortScience 45:1-6.

Song, N.-H. and Y.-J. Ahn. 2011. DcHsp17.7, a small heat shock protein in carrot, is tissuespecifically expressed under salt stress and confers tolerance to salinity. New Biotechnol. 28:698-704.

Sun, W., M. van Montagu, and N. Verbruggen. 2002. Small heat shock proteins and stress tolerance in plants. Biochim. Biophys. Acta 1577:1-9.

Wang, C., X. Gu, X. Wang, H. Guo, J. Geng, H. Yu, and J. Sunday. 2011. Stress response and potential biomarkers in spinach (Spinacia oleracea L.) seedlings exposed to soil lead. Ecotoxicol. Environ. Saf. 74:41-47.

Wang, C.R., X.R. Wang, Y. Tian, Y.G. Xue, X.H. Xu, Y.X. Sui, and H.X. Yu. 2008. Oxidative stress and potential biomarkers in tomato seedlings subjected to soil lead contamination. Ecotoxicol. Environ. Saf. 71:685-691.

Waters, E. 2013. The evolution, function, structure, and expression of the plant sHSPs. J. Expt. Bot. 64:391-403.

Waters, E.R., B.D. Aevermann, and Z. SandersReed. 2008. Comparative analysis of the small heat shock proteins in three angiosperm genomes identifies new subfamilies and reveals diverse evolutionary patterns. Cell Stress Chaperones 13:127-142.

Yi, S.-Y., A.-Q. Sun, Y. Sun, J.-Y. Yang, C.-M. Zhao, and J. Liu. 2006. Differential regulation of Lehsp23.8 in tomato plants: Analysis of a multiple stress-inducible promoter. Plant Sci. 171:398-407. 